\title{
The Autosomal Recessive Variety of Congenital Stationary Night-Blindness with Myopia*
}

\author{
VAZKEN M. DER KALOUSTIAN and SAHAG A. BAGHDASSARIAN
}

\author{
From the Departments of Pediatrics and Ophthalmology, American University of Beirut, Lebanon
}

Congenital stationary night-blindness associated with myopia may be transmitted by two types of inheritance: X-linked recessive (Worth, 1906; Nettleship, 1909 and 1912; Kleiner, 1923) and autosomal recessive (Nettleship, 1912; Vogt, 1923; Gassler, 1925; Akiya, 1935; Merin et al, 1970). There are only a few reports of either variety.

The present paper describes a family where 3 sibs are affected with the autosomal recessive form of congenital night-blindness with myopia. To our knowledge this is the third report of this condition in the English literature.

\section{Case Reports}

Case 1. S.D., a Syrian white girl, aged $11 \frac{1}{2}$ years (V.1, see Fig. 1) was observed to have an intermittent squint of the left eye at the age of $1 \frac{1}{2}$ years and inability to see in the dark at the age of $2 \frac{1}{2}$ years. Her vision was normal during daytime. She was first seen at the American University Hospital at $2 \frac{1}{2}$ years and was found to have bilateral myopia of $-8.0 \mathrm{sph}$. The rest of the physical examination was negative.

She was seen again 9 years later; there had been no change in the myopia and night-blindness. The general physical examination was normal.

A complete ocular examination was performed. This included tests of visual acuity, cycloplegic refraction, dark adaptation test using the Bausch and Lomb modified orthorater (Omarzu, 1968), and perimetry using the Goldman perimeter. The colour vision was tested by the A.O. H-R-R- pseudoisochromatic plates. The following results were obtained: Vision O.D. 20/30 with $-9.50 \mathrm{sph} .+1.25$ cyl. at axis $55^{\circ}$. Vision O.S. $20 / 50$ with $-9.00 \mathrm{sph}$. $+1.50 \mathrm{cyl}$. at axis $140^{\circ}$. She had $12^{4}$ of exotropia and $6^{4}$ left hypertropia. There were peripapillary chorioretinal degenerative myopic changes, and constriction of the peripheral fields. In 30 minutes she did not show any adaptation to the dark and her post-adaptation visual acuity was abnormal when compared with the norms established for the local population (Haddad, 1970). Colour vision was normal.

\footnotetext{
Received 8 June 1971.

* This study was supported by the Lebanese National Council for Scientific Research, grant No. 38-5757.
}

Laboratory data showed that she had a normal XX chromosomal pattern. Serum vitamin A was $38 \mu \mathrm{g} /$ $100 \mathrm{ml}$ and serum carotenoids was $65 \mu \mathrm{g} / 100 \mathrm{ml}$ (both within normal limits). Serum immunoelectrophoresis showed a qualitative rise in the level of $\alpha$ lipoproteins.

Case 2. M.D., a 10-year-old Syrian white boy (V.2) was the brother of case 1 . At about 1 year he was seen to have a squint in the left eye. At approximately $2 \frac{1}{2}$ years of age he would stumble after the sun had set because of difficulties of sight. However, his vision was good during the daytime. He was seen at the age of 5 years at the Department of Ophthalmology of the American University Hospital and was diagnosed to have night-blindness and myopia. The night-blindness has been stationary since then.

A complete ocular examination at the age of 10 years revealed the following: Vision O.D. 20/30 with $-5 \cdot 00$ sph.; O.S. $20 / 40$ with $-4.0 \mathrm{sph}$. $+1.00 \mathrm{cyl}$. at axis $155^{\circ}$. He had $10^{4}$ exotropia and $6^{4}$ left hypertropia. There were temporal peripapillary myopic crescents. There was constriction of the peripheral fields. In 30 minutes he had no adaptation to the dark and his post-adaptation visual acuity was abnormal. Colour vision was normal.

Laboratory examinations showed the level of serum vitamin $A$ to be $50 \mu \mathrm{g} / 100 \mathrm{ml}$ and serum carotenoids to be $122 \mu \mathrm{g} / 100 \mathrm{ml}$. Serum immunoelectrophoresis showed qualizative elevation of the $\alpha$ lipoproteins.

Case 3. K.D., a 7-year-old Syrian white boy (V.4), brother of cases 1 and 2, was first seen at the American University Hospital with a history suggestive of nightblindness and myopia since the age of 2 years. The general physical examination was normal.

A complete ocular examination revealed the following: Vision: O.D. $20 / 70$ with $-8.50 \mathrm{sph} .+2.00 \mathrm{cyl}$. at axis $5^{\circ}$; O.S. $20 / 70$ with $-8.50 \mathrm{sph} .+1.50$ cyl. at axis $160^{\circ}$. He had a latent nystagmus. With both eyes open, the vision was $20 / 40$ with glasses. He had temporal myopic crescents. Colour vision was normal. The visual fields and dark adaptation could not be assessed. However, after spending 30 minutes in a dark room with his parents, he could not locate them.

Laboratory data: serum vitamin A-38 $\mu \mathrm{g} / 100 \mathrm{ml}$; serum carotenoids-79 $\mu \mathrm{g} / 100 \mathrm{ml}$; serum immunoelectrophoresis revealed qualitative elevation of the $\alpha$ lipoproteins. 


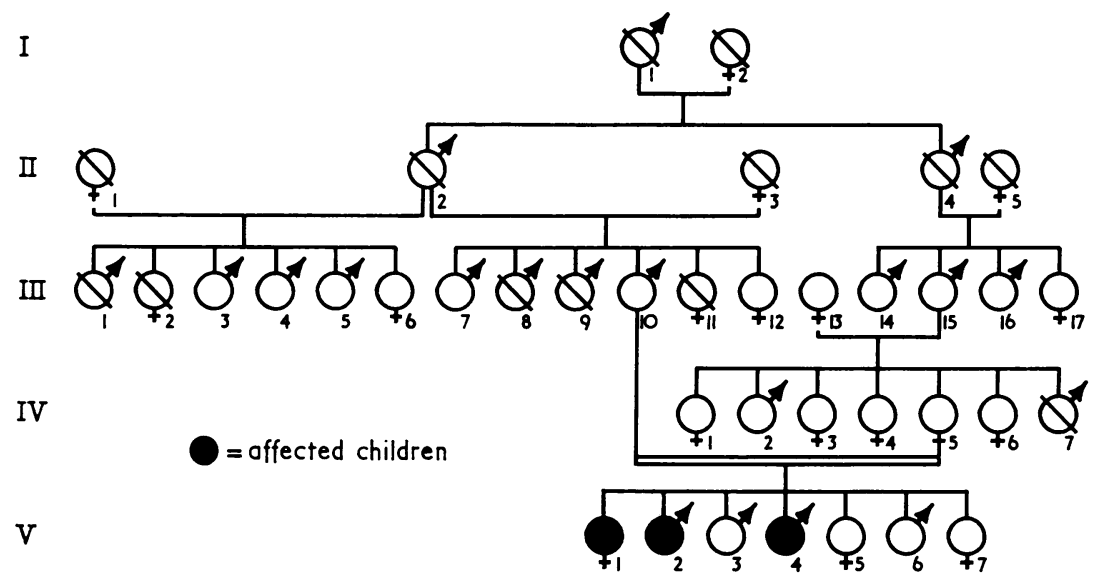

FIG. 1. Pedigree of the family.

The Family

The parents (III.10 and IV.5) of our 3 patients are closely related (Fig. 1). They have 7 children. Of these V.1, V.2, and V.4 are affected with myopia and night-blindness. After a detailed ocular examination performed on all the other members of the family, only the father was found to have myopia of $-1.50 \mathrm{sph}$. O.D. and $-0.50 \mathrm{sph}$. O.S. The dark adaptation could be assessed by the Bausch and Lomb modified orthorater method in both parents and in one child (V.3), all 3 had normal dark adaptation. Post-adaptation acuity was normal in both parents. However, V.3 did not cooperate for the completion of the test. In the younger children (V.5, V.6, and V.7) dark adaptation could not be tested. However, they gave no history of difficulty in night vision. There is no history of night-blindness or myopia in the family.

Complete blood typing was performed on all members of the family. It did not reveal any specific pattern suggestive of linkage with the disease. Serum vitamin A and carotenoid levels were normal in all.

\section{Discussion}

Patients with essential night-blindness with high grade myopia following the autosomal recessive pattern of inheritance were first recorded by Nettleship (1908 and 1912).

In 1923, Vogt reported the disease in an inbred Swiss kindred. Later, in 1925, Gassler studied the same Swiss family extensively; there were 10 affected members -7 females and 3 males aged between 19 and 47 years. It was not possible to decide whether myopia in these cases was congenital or had started during development. The latter alternative was considered by Gassler to be more likely. Since our patients were discovered to have myopia as early as $2 \frac{1}{2}$ years, we think that this severe myopia is congenitally associated with the night-blindness.
In our family, 3 children (a girl and 2 boys) out of 7 are affected. Except for mild myopia in the father, the parents are completely healthy and there is no history of either myopia or night-blindness in the relatives of either of the parents.

Aetiologically, congenital stationary night-blindness with myopia may either be due to two separate genes, each causing one of the manifestations, or due to a single gene responsible for both defects. We favour the single gene hypothesis because (1) the parents and relatives of our patients do not have essential night-blindness which, when unconnected with any other defect, is inherited as an autosomal dominant and because (2) there is no evidence of independent segregation of night-blindness and myopia in our pedigree (Fig. 1). Of course, there still is the remote-but unlikely-possibility that there are two genes on the same chromosome which are very close to each other, thus avoiding segregation.

We failed to locate the gene for this entity on any specific autosome, since blood grouping of all members did not reveal linkage to any specific blood group.

\section{Summary}

This paper describes a family in which 3 sibs (2 boys and a girl) are affected with congenital stationary night-blindness with myopia. The parents are closely related. A genetic aetiology involving a single gene is proposed. The autosomal recessive mode of inheritance is favoured.

We wish to thank Dr Raja Asfour from the Department of Pediatrics, American University of Beirut for his help, Dr V. N. Patwardhan from the Nutrition and Biochemistry Department of the US Naval Medical Research Unit no. 3-Cairo-for the determinations of 
serum vitamin A and carotenoid levels, Dr Ruth Sanger from the Lister Institute, London, for the detailed blood grouping, Dr Fuad Farah from the Department of Internal Medicine, American University of Beirut for the immunoelectrophoretic studies, and Dr Nadim Haddad from the Department of Public Health Administration, American University of Beirut for the interpretation of the visual studies.

\section{REFERENCES}

Akiya, J. (1935). Über sogenannte angeborene stationelle Hemeralopie im engeren Sinne. Acta Societatis Ophthalmologicae Faponice, 39, 476-496.

Gassler, V. J. (1925). Über eine bis jetzt nicht bekannte recessive Verknüpfung von hochgradiger Myopie mit angeborener Hemergalopie. Archiv der fulius Klaus-Stiftung für Vererbungsforschung, Sozialanthropologie und Rassenhygiene, 1, 259-272.

Haddad, N. A. (1970). UM/AUB Foint Vision Study, Vol. 2. Institute of Science and Technology, University of Michigan, Ann Arbor, Michigan.
Kleiner, W. (1923). Über den grossen schweizerischen Stammbaum, in dem sich Kurzsichtigkeit mit Nachtblindheit kombiniert forterbt. Archiv für Rassen- und Gesellschaftsbiologie, 15, 1-17.

Merin, S., Rowe, H., Auerbach, E., and Landau, J. (1970). Syndrome of congenital high myopia with nyctalopia. American Fournal of Ophthalmology, 70, 541-547.

Nettleship, E. (1908). Congenital night-blindness. The Royal London Ophthalmic Hospital Reports, 17, 406-410.

Nettleship, E. (1909). On some hereditary diseases of the eye. Transactions of the Ophthalmological Society of the United Kingdom, 29, 57-198.

Nettleship, E. (1912). A pedigree of congenital night-blindness with myopia. Transactions of the Ophthalmological Society of the United Kingdom, 32, 21-45.

Omarzu, C. A. (1968). Some Tests of Night and Day Vision. Institute of Science and Technology, University of Michigan, Ann Arbor, Michigan.

Vogt, A. (1923). Ueber Vererbung von Augenleiden. Schweizerische Medizinische Wochenschrift, 53, 188-193.

Worth, C. (1906). Hereditary influence in myopia. Transactions of the Ophthalmological Society of the United Kingdom, 26, 141144. 